University of Nebraska - Lincoln

DigitalCommons@University of Nebraska - Lincoln

\title{
Implications of Water Supply for Indigenous Americans during Holocene Aridity Phases on the Southern High Plains, USA
}

\author{
Warren W. Wood \\ U.S. Geological Survey, wwwood@usgs.gov \\ Stephen Stokes \\ University of Oxford, stephen.stokes@geography.ox.ac.uk \\ Julie Rich \\ University of Oxford, jrich@weber.edu
}

Follow this and additional works at: https://digitalcommons.unl.edu/usgsstaffpub

Wood, Warren W.; Stokes, Stephen; and Rich, Julie, "Implications of Water Supply for Indigenous Americans during Holocene Aridity Phases on the Southern High Plains, USA" (2002). USGS Staff -Published Research. 580.

https://digitalcommons.unl.edu/usgsstaffpub/580

This Article is brought to you for free and open access by the US Geological Survey at DigitalCommons@University of Nebraska - Lincoln. It has been accepted for inclusion in USGS Staff -- Published Research by an authorized administrator of DigitalCommons@University of Nebraska - Lincoln. 


\title{
Implications of Water Supply for Indigenous Americans during Holocene Aridity Phases on the Southern High Plains, USA
}

\author{
Warren W. Wood ${ }^{1}$ \\ MS 430, National Center, U.S. Geological Survey, Reston, Virginia 20192 \\ E-mail:wwwood@usgs.gov \\ and \\ Stephen Stokes and Julie Rich ${ }^{2}$ \\ School of Geography and the Environment, University of Oxford, Oxford OX1 3TB, United Kingdom \\ Received January 29, 2002; published online August 22, 2002
}

\begin{abstract}
Springs in the 40 to 50 large lake basins $\left(>15 \mathrm{~km}^{2}\right)$ on the southern portion of the Southern High Plains (SHP) were active during periods of aridity in the Holocene when there may have been human habitation of the area. Eolian erosion of the lake floors and lunette accretion occurred as groundwater levels declined in response to decreased groundwater recharge. The declining lake floor associated with eolian erosion allowed groundwater evaporative discharge to continue, thus maintaining a groundwater gradient toward the lake. This hydrologic condition was favorable for a relatively continuous spring discharge to the lake, independent of the elevation of the lake floor. To evaluate the postulated dynamic equilibrium critical to this conclusion, 17 optically stimulated ages were determined from a 17.7-m deep core of a lunette adjacent to Double Lakes, Texas $\left(33^{\circ} 13^{\prime} 15^{\prime \prime} \mathrm{N}, 101^{\circ} 54^{\prime} 08^{\prime \prime} \mathrm{W}\right)$. The core yielded sediment accumulation dates of $11,500 \pm 1100,6500 \pm 700$, and $4900 \pm 500 \mathrm{yr}$ B.P., corresponding broadly with periods of aridity known from other evidence. Based on analysis of this lunette, it is concluded that springs in Double Lakes basin probably existed throughout the Holocene with discharges similar to those observed historically. We assumed that similar dynamic equilibrium existed in the other large lake basins in the SHP and that these springs could have provided a continuous source of water for indigenous peoples during periods of prolonged aridity. The dynamic equilibrium that is proposed in this study is applicable not only to other arid and semiarid geographic areas with wind-erodible material but also over different geologic times. (๑) 2002 University of Washington.

Key Words: Southern High Plains; Texas; New Mexico; springs; groundwater; lake basins; geomorphology; Holocene; aridity; lunettes.
\end{abstract}

\footnotetext{
${ }^{1}$ To whom correspondence should be addressed.

${ }^{2}$ Now at Department of Geography, Weber State University, Ogden, Utah 84408-2507.
}

\section{INTRODUCTION}

It is known that there were periods of extended aridity in the Holocene on the Southern High Plains (SHP) of Texas and New Mexico, USA (Forman et al., 2001) (Fig. 1). Holliday (2000) documented episodic droughts between 11,000 and $10,000{ }^{14} \mathrm{C}$ yr B.P., and Meltzer (1999) and Holliday (1995) documented aridity between 7500 and $5000{ }^{14} \mathrm{C}$ yr B.P. Holliday (2001) identified dune-field and sand-sheet activity after 7500 to $5000{ }^{14} \mathrm{C}$ yr B.P., suggesting periods of aridity in the late Holocene consistent with the review by Forman et al. (2001). Meltzer (1995) challenged the geoarcheological community to identify new locations that might provide information on how humans adjusted under these conditions. In response to this suggestion, we assumed that potable water was the limiting condition. Thus, an attempt was made to identify likely sources of permanent water during periods of aridity.

Humans require 2-3 L of water each day for long-term survival (Cember, 1969). Although succulents, wild melons, and other fleshy cucurbits could have provided some moisture, permanent sources of water must have been available if there were permanent occupation. Sheehan (1994) suggested that during drought, settlements of indigenous Americans on the Great Plains formed around "refugia," localities where permanent water was available. Because of its weight and bulk, water is difficult to transport long distances, and the refugia had an effective radius of approximately $80 \mathrm{~km}$ (Sheehan, 1994). In reality, this range appears to be a maximum and would be tempered by temperature, relative humidity, wind speed, topography, vegetative cover, game density, and other environmental factors. Kelly (1995) suggested that a distance of $10 \mathrm{~km}$ might be more realistic. Regardless of the actual distance traveled, surface water currently is limited both temporally and spatially and is believed to have been extremely restricted during extended periods of aridity (Meltzer, 1999). Meltzer (1999) evaluated the likely response 


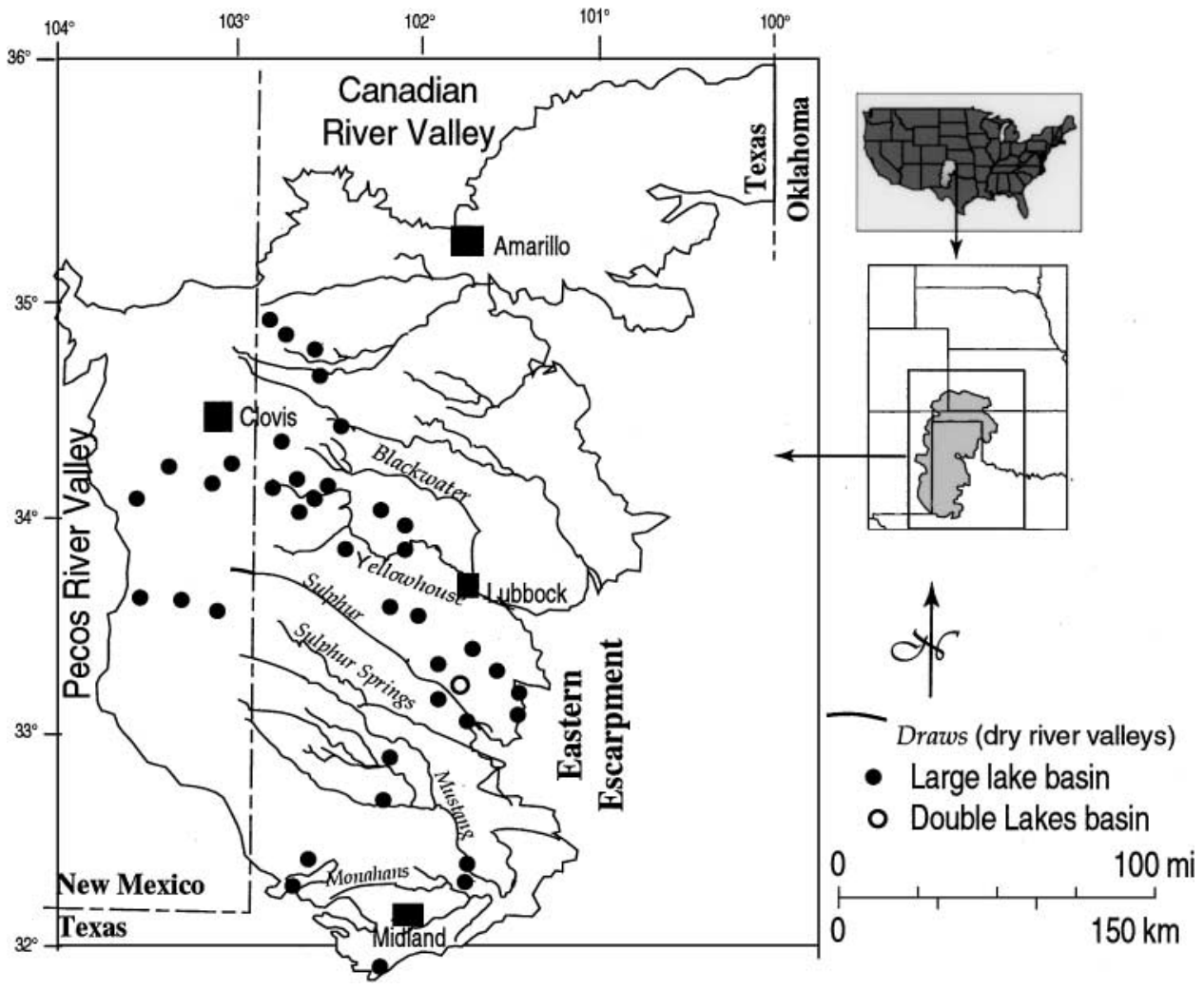

FIG. 1. Map showing large saline lake basins and dry river valleys (draws) on the Southern High Plains of Texas and New Mexico.

of indigenous Americans to the drying climate during the middle Holocene and identified 60 dug wells in draws (dry river valleys) during this period (Fig. 1). Although draws would have provided a source of water during times of high water table, it is likely that the water supply was limited as declining groundwater levels combined with the filling of draws with eolian sand during periods of aridity (Holliday, 1995, 2000). Because of the dynamic equilibrium between the elevation of the lake floor and the elevation of the groundwater table, it is proposed that many of the springs that have existed historically in the 40 to 50 large lake basins $\left(>15 \mathrm{~km}^{2}\right)$ (Brune, 1981) were also active throughout periods of aridity in the Holocene. The following analysis focuses on this hypothesis of dynamic equilibrium and its hydrologic significance with respect to springs in these basins.

\section{HYDROGEOLOGIC SETTING}

The $81,000-\mathrm{km}^{2}$ area of the SHP is defined by the elevated constructional plateau south of the Canadian River valley, east of the Pecos River valley, and west of the Eastern Escarpment (Fig. 1). To the south, sediments forming the SHP thin and overlap the Cretaceous rocks of the Edwards Plateau. The igneous/ metamorphic basement complex is overlain by a thick sequence of Paleozoic and Mesozoic sediments that, in turn, are overlain by the extensive Ogallala Formation (Fm.) of Miocene/ Pliocene age. The eolian Blackwater Draw Fm. of Pleistocene age overlies this sequence. Numerous isolated eolian and lacustrine Quaternary sediments are also present in the area (Reeves, 1966). This article focuses on the groundwater hydrology associated with the Ogallala and younger formations that form the bulk of the High Plains aquifer system in the SHP (Gutentag et al., 1984).

The Ogallala Fm. is a remnant of a series of overlapping, but mostly inset, coalescing, alluvial deposits that filled incised bedrock valleys with clays, sands, and gravels derived from the rising Rocky Mountains (Hawley et al., 1976). Relief on the incised Mesozoic and Paleozoic bedrock is several tens of meters (Reeves and Reeves, 1996). The Ogallala on the SHP averages $100 \mathrm{~m}$ in thickness (Reeves and Reeves, 1996) and is cemented locally by pedogenic calcrete, particularly in the upper portion. The upper part of the Ogallala Fm. is fine-grained eolian sand and silt derived initially from the flood plains of the anastomosing streams on the developing plain (Gustavson and Winkler, 1988). Original deposition of the Ogallala extended at least $200 \mathrm{~km}$ further east than the present-day exposures (Frye and Leonard, 1957). The surface of the SHP slopes at approximately $2 \mathrm{~m} / \mathrm{km}$ to the southeast, with elevation declining from over $1400 \mathrm{~m}$ to less than $915 \mathrm{~m}$.

To the west, the northward incursion of the ancestral Pecos River during Pliocene/Pleistocene times had profound effects on the geomorphology of the area. The Pecos pirated the eastwardflowing streams and intercepted the supply of sediment from 
the Rocky Mountains that had been building the alluvial apron. Once the sediment supply was eliminated, the distal eastern edge of the apron started its net westward erosion that continues today (Gustavson et al., 1991). Similarly, development of the Canadian River system in the north isolated the SHP from the northern segment of the Great Plains and intercepted any southeasternflowing ground or surface water. The cessation of a sediment supply stabilized the surface and permitted development of a pedogenic "caprock" calcrete 3 or $4 \mathrm{~m}$ thick that forms the upper surface of the Ogallala Fm. and gives the area its distinctive plateau topography. The elevation of the surface of the Ogallala Fm. was controlled by a dynamic equilibrium of surface water, groundwater, and eolian processes. Covering the Ogallala with a mantle up to $25 \mathrm{~m}$ thick is the Pleistocene Blackwater Draw Fm. containing well-developed soil horizons, calcrete, and eolian deposits of clays, silts, and fine sand derived from the developing Pecos and Canadian River valleys (Gustavson et al., 1991).

Late Pleistocene/Holocene lacustrine sediments superimposed on the eolian sediments are found in approximately 20,000 shallow basins (playas) on the SHP (Curtis and Beierman, 1980). The larger Pleistocene lake basins have a complex, discontinuous Quaternary stratigraphy that varies from lake to lake (Gustavson et al., 1991). Lunettes (eolian dunes formed from lacustrine sediment derived from adjacent lakes) are present on the lee side of the larger lake basins, and outcrops of Mesozoic bedrock occur at the topographically up-gradient edges of these basins (Brand, 1953). The seven or eight major draws that are incised in the surface of the SHP were probably formed or enlarged in the Late Pleistocene when the precipitation was greater and the groundwater table was higher (Sanford and Wood, 1995). Reeves and Reeves (1996), Gustavson et al. (1991), and Osterkamp et al. (1987) provide detailed descriptions of the geology and stratigraphy of the Miocene through Holocene deposits. Holliday (1995) provides a detailed description of eolian fill in the draws.

The SHP currently exhibits little overland runoff as $98 \%$ of the area is drained internally by 20,000 small $\left(<15 \mathrm{~km}^{2}\right)$ playa basins (Osterkamp and Wood, 1984). The surface of the groundwater table slopes to the southeast at approximately $2 \mathrm{~m} / \mathrm{km}$ and generally mirrors the regional topography (Cronin, 1964; Gutentag et al., 1984; Knowles et al., 1984). Predevelopment groundwater recharge to the system was between 11 and $12 \mathrm{~mm} / \mathrm{yr}$ (Theis, 1937; Wood and Sanford, 1995a) and was focused in the floors of the playa basins (Wood et al., 1997).

Historically, precipitation on the SHP increases from $330 \mathrm{~mm}$ in the southwest to $530 \mathrm{~mm}$ in the northeast and averages approximately $450 \mathrm{~mm}$ (Fig. 2) (Larkin and Bomar, 1983), although there is large temporal and spatial variation. Ninety years of precipitation records from Lubbock, Texas $\left(33^{\circ} 39^{\prime} \mathrm{N}, 101^{\circ} 49^{\prime} \mathrm{W}\right.$, elevation $992 \mathrm{~m}$, Fig. 2), indicate that annual precipitation ranged between $222 \mathrm{~mm}$ in 1917 and $1030 \mathrm{~mm}$ in 1940 and averaged $471 \mathrm{~mm}$. Precipitation is concentrated in May through October, (National Oceanic and Atmospheric Administration, 2002). Annual potential evaporation averages nearly $1900 \mathrm{~mm}$ and increases toward the south (Fig. 2). Average monthly temperature in Lubbock ranges between $3.8^{\circ} \mathrm{C}$ in January and $26.7^{\circ} \mathrm{C}$

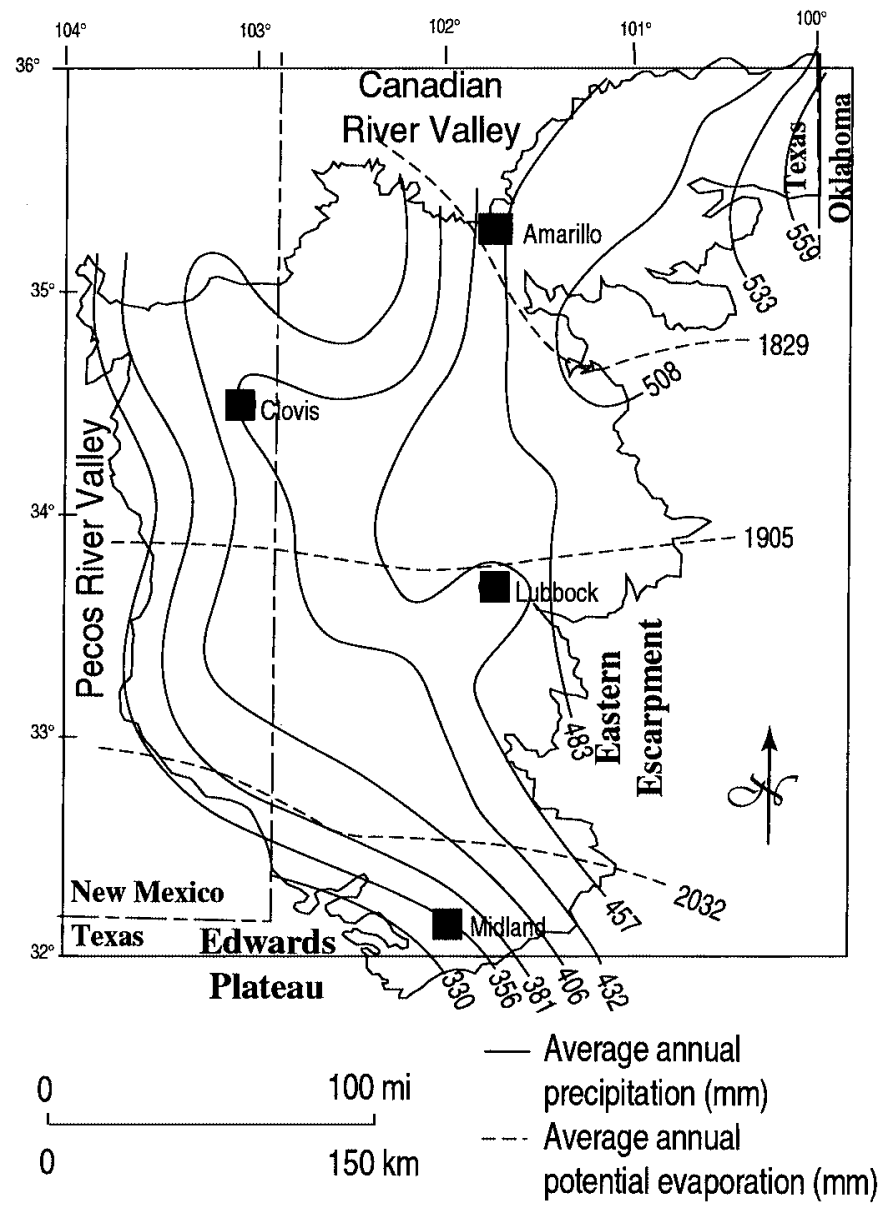

FIG. 2. Map showing contours of annual precipitation and potential evaporation on the Southern High Plains of Texas and New Mexico (modified after Larkin and Bomar, 1983).

in July (National Oceanic and Atmospheric Administration, 2002).

The down-cutting of the Canadian and Pecos Rivers and the erosion of the eastern escarpment coupled with the high topographic elevation of the SHP have isolated the aquifer hydrologically. Thus, the source of groundwater to the aquifer is direct precipitation on the surface of the SHP; there is no lateral or upward groundwater flux into the aquifer. There is, however, a small downward groundwater flux through the underlying, low permeability, Mesozoic and Paleozoic sediments (Wirojanagud et al., 1986). Evaporation losses directly from the water table are believed to be insignificant because the depth to groundwater is below the effective evaporation limit, except in the 40 or 50 larger basins associated with the saline lakes. Prior to the development of irrigated agriculture, most groundwater discharged to springs and seeps along the eastern escarpment. Because the regional groundwater table of the High Plains aquifer slopes to the southeast, the springs along the Pecos River or Canadian River escarpments had little discharge. Because of the large volume of groundwater withdrawal for irrigation, most of the springs on the eastern escarpment identified by White et al. (1946) and 
Brune (1981) are either no longer active or have a greatly reduced discharge.

\section{SOURCES OF WATER}

\section{Playa Basins}

The most conspicuous water-related features on the SHP are the 20,000 small (floors generally less than $2 \mathrm{~km}^{2}$ ) playa basins south of the Canadian River. Many of these karstlike features result from eolian depressions that were enlarged by dissolution of calcrete within the Blackwater Draw and Ogallala Fms. (Osterkamp and Wood, 1987; Wood and Osterkamp, 1987), although other mechanisms for their origin and development have been proposed (Gustavson et al., 1995). Under present climatic conditions, playa basins receive significant precipitation only from May through October (National Oceanic and Atmospheric Administration, 2001). Little, if any, water is retained between November and April because of the basins' small volume, high initial recharge rate, and large potential evaporation. Anecdotal evidence indicates that individual playa lakes are filled approximately once every 2 or $3 \mathrm{yr}$ and then typically dry within a few months. Neither the mineralogy of the sediments nor the stratigraphy in the basins suggests that they were filled with water on a permanent basis. Had they contained water continuously, it would have been saline. Almost certainly the potential evaporation rate during periods of aridity would have exceeded the current potential evaporation/rainfall value of 4 (Fig. 2) that presently creates saline conditions within a few years. Thus, playa basins might have provided occasional "lucky" finds of water, but they would not have been suitable candidates for permanent water supply, or "refugia," for indigenous Americans on the SHP.

\section{Springs on the Eastern Escarpment}

Hundreds of springs and seeps existed along the eastern escarpment before major development of the groundwater for irrigation (White et al., 1946; Brune, 1981). Because of the large storage capacity of the High Plains aquifer, the change in discharge of these springs was likely to be relatively small, even during periods of extended aridity. Steady-state estimates of predevelopment discharge at the escarpment can be made using the following modification of Darcy's Law:

$$
Q=(q)(A),
$$

where $Q$ is discharge at the face of the escarpment $\left(L^{3} / T\right), q$ is groundwater recharge flux $(L / T)$ where $L$ is length and $T$ is time, and $A$ is area of recharge $\left(L^{2}\right)$.

Using a predevelopment groundwater recharge flux of $11 \mathrm{~mm} /$ $\mathrm{yr} / \mathrm{m}^{2}$ (Theis, 1937; Wood and Sanford, 1995a), a 1-km-wide by 200-km-long strip of the aquifer parallel to the flow direction would have an annual recharge of approximately $2.2 \times 10^{9} \mathrm{~L}$. Under steady-state conditions, this same volume of water must discharge at the eastern escarpment, or $4.2 \times 10^{3} \mathrm{~L} / \mathrm{min} /$ linear $\mathrm{km}$ of the escarpment. This discharge is a combination of springs and diffuse seepage lost to evaporation at the face of the escarpment. This analysis assumes that there is little or no loss by evaporation from the groundwater, a reasonable assumption given the significant depth to water table over most of the area. If these springs had been the only major source of water, however, the indigenous American population would have been restricted to a fringe a few $\mathrm{km}$ wide along the margins of the eastern escarpment. Because there is evidence of more extensive habitation (Johnson and Holliday, 1986, 1995; Hofman, 1989; Meltzer, 1999), it is concluded that more extensive water resources must have been available.

\section{Draws}

Workers have clearly established the existence of springs in many of the draws as sources of water for indigenous Americans on the SHP. Some locations, such as Lubbock Lake in Yellowhouse Draw near Lubbock, Texas, have apparently been permanent sources of water for the last 12,000 yr (Johnson and Holliday, 1986). Springs in Blackwater Draw have been active in historical times (Brune, 1981), and clearly, Running Water Draw was named because of its continuous discharge (Brune, 1981). In addition, Meltzer (1999) identified many dug wells in draws in the southern half of the SHP. Because of a lack of detailed paleoclimate information, it is impossible to determine if groundwater levels in historical times were the same, elevated, or depressed relative to average conditions of the Holocene.

Springs in the draws result from the intersection of the groundwater table with the draw's surface. The condition controlling the water-table elevation in a steady-state aquifer system, in which uniform recharge occurs on the surface and discharge occurs at the aquifer boundaries, is given by Darcy's Law:

$$
q=-k(\Delta h / \Delta l),
$$

where $q$ is the discharge flux $(L / T), k$ is the hydraulic conductivity $(L / T), \Delta h / \Delta l$ is the gradient of the water table (dimensionless), and the negative sign reflects flow from higher to lower potential. Mass-balance arguments for steady state require that recharge must equal discharge. Making the reasonable assumption that hydraulic conductivity remains constant, a change in discharge caused by a change in recharge must be reflected in a change in the gradient (Eq. 2). Because of the need to maintain discharge from the aquifer by maintaining a relatively constant discharge cross-section, the change in groundwater elevation will be greater near the groundwater divide than near the discharge zone. Thus, springs in draws closer to the groundwater divide, near their headwaters, have greater elevation response to recharge rates (climate change) than springs near the distal end. It follows that during periods of aridity, springs in the distal areas of draws would have maintained their discharge for longer periods than those in the proximal areas.

Further exacerbating access to groundwater in these draws during periods of aridity was the accumulation of eolian 
sediment (Holliday, 1995, 2000). This addition makes the depth to water even greater than that caused by water-level decline alone. Meltzer (1999) provided references to dug wells in Black water, Sulphur Springs, Mustang Springs, and Monahans Draws (Fig. 1), and it is reasonable to expect that continued investigation may reveal additional dug wells in other draws. The technology, workforce, lithology, degree of cementation, materials, and other factors required to construct and develop deep wells may have exceeded the resources available to indigenous Americans in the Holocene, hence, the desirability to look elsewhere for permanent sources of water.

\section{Large Lake Basins}

Another potential source of water for indigenous Americans was springs in the 40 to 50 larger $\left(>15 \mathrm{~km}^{2}\right)$ basins shown on 1:250,000 topographic maps of the SHP (Fig. 1). Most of these basins lie southwest of a line connecting Lubbock, Texas, and Clovis, New Mexico, and are incised 20 to $30 \mathrm{~m}$ below the regional surface. A sense of the size of the large basins (Double Lakes) relative to that of the small playa basins is apparent in Figure 3. Because of the internal drainage of the SHP, these large basins have relatively small drainage areas to capture surface water; thus, most of the water evaporated from them is groundwater (Wood and Sanford, 1995b). This evaporation creates a cone of depression in the groundwater table surrounding the lake, causing groundwater flow into these basins from all directions (Fig. 4). Assuming uniform hydraulic conductivity, the greatest gradient will be in the up-gradient direction of the regional groundwater flow, or from the northwest (Fig. 5). The north, west, and northwest sides of the basins are, in fact, where a number of springs are observed (Brune, 1981).

Wood et al. (1992) evaluated the origin of these large lake basins and concluded that most developed by eolian processes but have been filled and emptied several times since their initial

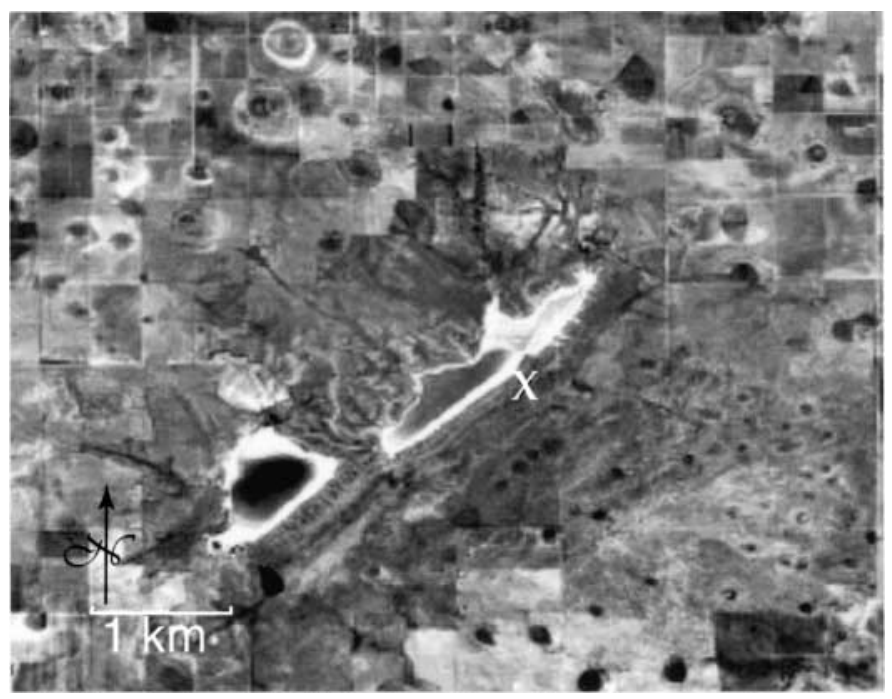

FIG. 3. High altitude photograph of Double Lakes, Lynn County, Texas. X indicates the location of core.

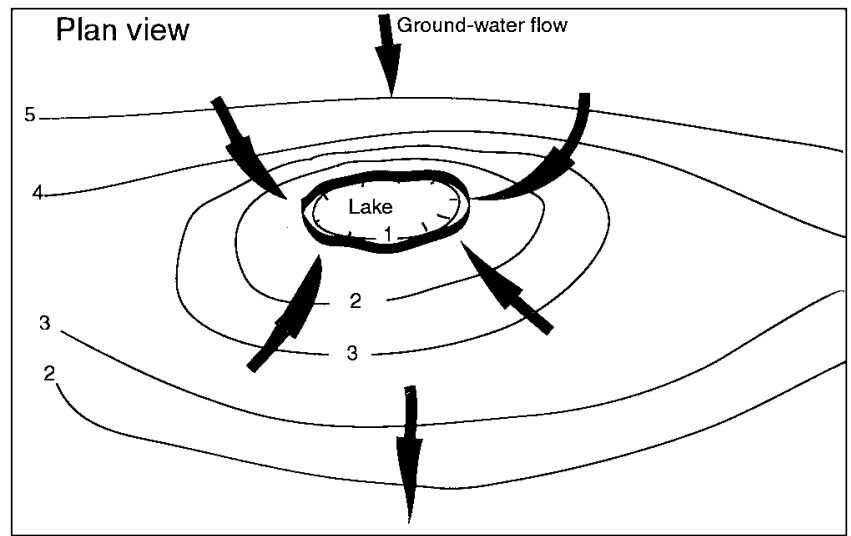

FIG. 4. Plan view of generalized groundwater contours (arbitrary units of head) and flow lines surrounding a representative large lake basin on the Southern High Plains of Texas and New Mexico. Note that the contours are more closely spaced in the up-gradient direction (top of figure).

(middle/late Pleistocene?) formation. Because of the salinity of the groundwater, there is no vegetation on the floors of these basins. May Spring at Tahoka Lake, a representative spring associated with these large basins, is shown in Figure 6. Brune (1981) reported discharge of $3.4 \mathrm{~L} / \mathrm{s}$ (liters per second) from this spring on December 13, 1974. Discharge from the springs in many of the large lake basins ranged from less than $1 \mathrm{~L} / \mathrm{s}$ to over $10 \mathrm{~L} / \mathrm{s}$ (Brune, 1981).

Elevation of the floor of these basins is hypothesized to be controlled by the dynamic equilibrium between eolian activity and the elevation of the groundwater table. The equilibrium elevation position of the basin floor is at the top of the groundwater capillary zone. If the groundwater table rises, standing water will accumulate in the lake basins and trap eolian and alluvial sediment, increasing the thickness of lacustrine deposits and reestablishing the elevation consistent with the new groundwater table. Conversely, if the water table declines, the wind erodes the surface to the top of the capillary zone because eolian processes cannot erode below the water table. The eroded sediment typically forms lunettes (Bowler, 1983). There is always some lag time in the readjustment of the surface associated with a changing water table, but this is believed to be small (within a few years).

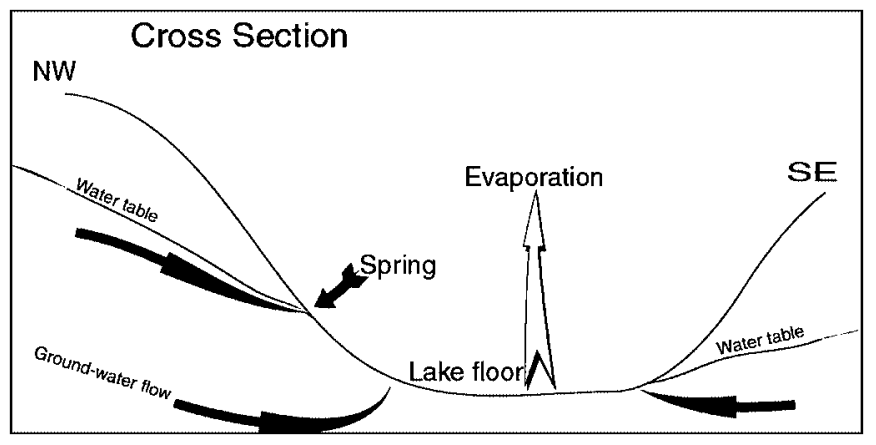

FIG. 5. Cross section of a representative large lake basin showing groundwater flow lines in response to evaporation from the lake floor. 


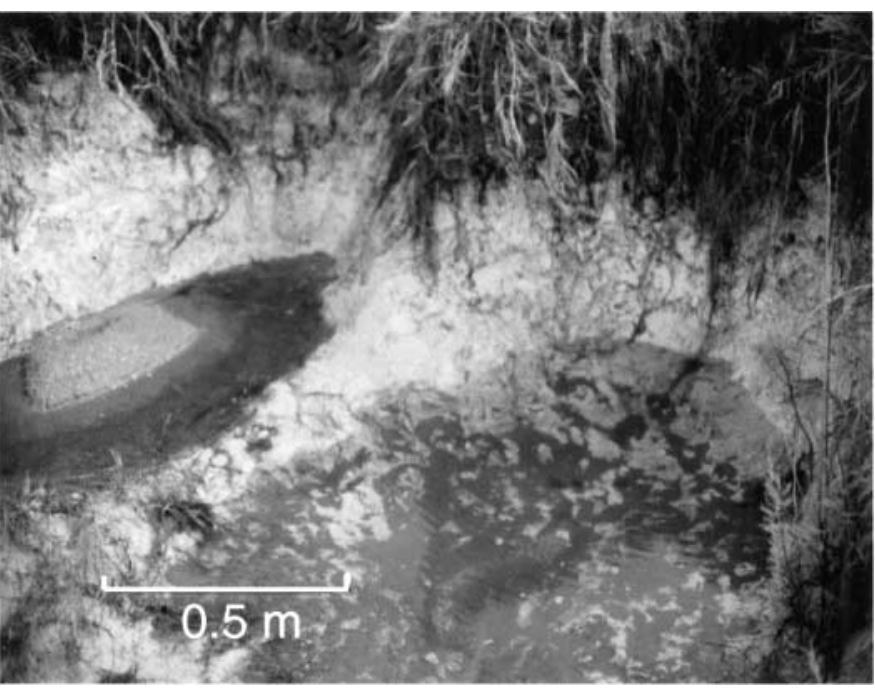

FIG. 6. Photograph of May Spring, Tahoka Lake, Lynn County, Texas 1983.

There is also some moisture added to the lake basin by discharge from the springs, but the area affected by the spring discharge is insignificant and very local compared to the area of the floor.

It is explicitly assumed that the sediment cover of the bedrock is sufficiently thick that the bedrock is not controlling the lakefloor elevation. The changing elevation of the lake floor corresponds to the changing water levels and maintains a relatively constant groundwater gradient toward the lake. The absolute elevation of the spring mouth will change, but its differential elevation relative to the lake floor will remain relatively constant; thus, discharge from the spring will remain approximately the same. This condition ensures a discharge of water at these springs, even under arid conditions.

\section{APPROACH AND METHODS}

Testing the hypothesis of dynamic equilibrium between groundwater and eolian processes is critical to the argument that springs will continue to flow during periods of aridity. It is generally difficult to reconstruct paleo-groundwater elevations by evaluation of the aquifer; however, if a dynamic equilibrium exists between the eolian process and the water table, it should be possible to measure this eolian response in the associated lunettes. It is known that there were several major periods of aridity during the Holocene on the SHP. From descriptions of duration and intensity of these periods of aridity, it was hypothesized that the water table likely would have declined and thus provided an opportunity for eolian processes to form lee-side lunettes. Stokes (1994) and Rich et al. (1999) established that the upper few meters of lunettes at Double Lakes, Texas, were Holocene in age and thus might provide the sediment record corresponding to these periods of aridity.

Because of the lack of well-defined soil horizons suitable for radiocarbon dating in the rapidly accumulating lunettes (Table 1)

TABLE 1

Optical Stimulated Luminescence Dates of a Core from the Inner Lunette at Double Lakes, Texas $\left(33^{\circ} 13^{\prime} 15^{\prime \prime} \mathrm{N}, 1^{\circ}{ }^{\circ} 54^{\prime} 08^{\prime \prime} \mathrm{W}\right)$, Elevation $963 \mathrm{~m}$ above Mean Sea Level

\begin{tabular}{|c|c|c|c|c|c|c|c|c|c|c|c|c|c|c|}
\hline \multirow[b]{2}{*}{ Sample ID } & \multirow{2}{*}{$\begin{array}{l}\text { Depth } \\
\text { (m) BLS }\end{array}$} & \multirow[b]{2}{*}{ WF } & \multicolumn{2}{|c|}{ K } & \multicolumn{2}{|c|}{ Th } & \multicolumn{2}{|c|}{$\mathrm{U}$} & \multirow{2}{*}{$\begin{array}{c}\text { Cosmic } \\
\text { dose rate } \\
\text { mGy/a }\end{array}$} & \multicolumn{2}{|c|}{ Dose rate } & \multirow[b]{2}{*}{$\mathrm{D}_{\mathrm{e}}(\mathrm{Gy})$} & \multicolumn{2}{|c|}{ Age } \\
\hline & & & $\%$ & error & $(\mathrm{ppm})$ & error & (ppm) & error & & $\mathrm{mGy} / \mathrm{a}$ & & & (a) & error, $1 \sigma$ \\
\hline SogTX99/3/1A & 0.3 & 0.10 & 1.34 & \pm 0.07 & 6.24 & \pm 0.31 & 6.09 & \pm 0.30 & 0.20 & 3.21 & \pm 0.28 & $1.6 \pm 0.11$ & 500 & \pm 60 \\
\hline SogTX99/3/1B & 0.9 & 0.07 & 1.25 & \pm 0.06 & 5.04 & \pm 0.25 & 10.30 & \pm 0.52 & 0.19 & 4.13 & \pm 0.36 & $21 \pm 1$ & 5100 & \pm 500 \\
\hline SogTX99/3/3B & 2.4 & 0.05 & 0.52 & \pm 0.03 & 1.72 & \pm 0.09 & 9.13 & \pm 0.46 & 0.15 & 3.02 & \pm 0.26 & $14 \pm 0.3$ & 4700 & \pm 400 \\
\hline SogTX99/3/4A & 3.4 & 0.11 & 0.96 & \pm 0.05 & 3.54 & \pm 0.18 & 12.50 & \pm 0.63 & 0.13 & 4.08 & \pm 0.35 & $30 \pm 1$ & 7400 & \pm 700 \\
\hline SogTX99/3/4B & 4 & 0.09 & 0.72 & \pm 0.04 & 2.55 & \pm 0.13 & 14.00 & \pm 0.70 & 0.12 & 4.21 & \pm 0.36 & $30 \pm 0.7$ & 7200 & \pm 600 \\
\hline SogTX99/3/5B & 5.5 & 0.06 & 0.46 & \pm 0.02 & 1.84 & \pm 0.09 & 13.30 & \pm 0.67 & 0.10 & 3.86 & \pm 0.33 & $27 \pm 0.5$ & 7000 & \pm 600 \\
\hline SogTX99/3/6A & 6.4 & 0.16 & 1.29 & \pm 0.06 & 4.95 & \pm 0.25 & 23.60 & \pm 1.18 & 0.09 & 6.64 & \pm 0.58 & $39 \pm 1$ & 5900 & \pm 500 \\
\hline SogTX99/3/6B & 7 & 0.10 & 0.72 & \pm 0.04 & 2.52 & \pm 0.13 & 16.50 & \pm 0.83 & 0.09 & 4.70 & \pm 0.41 & $33 \pm 0.5$ & 7000 & \pm 600 \\
\hline SogTX99/3/7A & 8 & 0.11 & 0.66 & \pm 0.03 & 2.86 & \pm 0.14 & 27.50 & \pm 1.38 & 0.08 & 7.13 & \pm 0.62 & $42 \pm 1$ & 5800 & \pm 500 \\
\hline SogTX99/3/8A & 9.4 & 0.15 & 1.01 & \pm 0.05 & 3.72 & \pm 0.19 & 29.20 & \pm 1.46 & 0.07 & 7.61 & \pm 0.66 & $47 \pm 1$ & 6100 & \pm 600 \\
\hline SogTX99/3/8B & 10 & 0.19 & 1.09 & \pm 0.05 & 3.87 & \pm 0.19 & 33.30 & \pm 1.67 & 0.06 & 8.19 & \pm 0.71 & $52 \pm 1$ & 6400 & \pm 600 \\
\hline SogTX99/3/9A & 11 & 0.17 & 0.95 & \pm 0.05 & 3.82 & \pm 0.19 & 38.80 & \pm 1.94 & 0.06 & 9.44 & \pm 0.82 & $48 \pm 0.7$ & 5100 & \pm 400 \\
\hline SogTX99/3/10A & 12.5 & 0.12 & 1.17 & \pm 0.06 & 4.70 & \pm 0.24 & 15.00 & \pm 0.75 & 0.05 & 4.77 & \pm 0.41 & $31 \pm 1$ & 6600 & \pm 600 \\
\hline SogTX99/3/10B & 13 & 0.14 & 1.09 & \pm 0.05 & 4.04 & \pm 0.20 & 18.20 & \pm 0.91 & 0.05 & 5.26 & \pm 0.46 & $35 \pm 1$ & 6600 & \pm 600 \\
\hline SogTX99/3/11A & 14 & 0.06 & 1.05 & \pm 0.05 & 3.02 & \pm 0.15 & 4.55 & \pm 0.23 & 0.04 & 2.32 & \pm 0.20 & $27 \pm 1$ & 11,000 & \pm 1000 \\
\hline SogTX99/3/11B & 14.6 & 0.07 & 0.72 & \pm 0.04 & 2.93 & \pm 0.15 & 2.69 & \pm 0.13 & 0.04 & 1.54 & \pm 0.13 & $178 \pm 12$ & 115,000 & $\pm 12,000$ \\
\hline SogTX99/3/12A & 15.5 & 0.14 & 1.26 & \pm 0.06 & 4.86 & \pm 0.24 & 4.48 & \pm 0.22 & 0.04 & 2.41 & \pm 0.21 & $235 \pm 12$ & 98,000 & $\pm 10,000$ \\
\hline SogTX99/3/12B & 16 & 0.04 & 0.69 & \pm 0.03 & 2.62 & \pm 0.13 & 1.89 & \pm 0.09 & 0.04 & 1.34 & \pm 0.12 & $151 \pm 8$ & 113,000 & $\pm 11,000$ \\
\hline SogTX99/3/13A & 17 & 0.11 & 1.31 & \pm 0.07 & 4.69 & \pm 0.23 & 4.07 & \pm 0.20 & 0.03 & 2.42 & \pm 0.21 & $231 \pm 3$ & 96,000 & \pm 8000 \\
\hline SogTX99/3/13B & 17.7 & 0.14 & 1.05 & \pm 0.05 & 3.86 & \pm 0.19 & 5.93 & \pm 0.30 & 0.03 & 2.48 & \pm 0.21 & $304 \pm 11$ & 122,000 & $\pm 12,000$ \\
\hline
\end{tabular}

$\mathrm{WF}=$ corrected and averaged field moisture content; $\mathrm{K}=$ Potassium (percentage); Th $=$ Thorium (parts per million); $\mathrm{U}=\mathrm{Uranium}($ parts per million); Gy = Grays; $\mathrm{D}_{\mathrm{e}}=$ Dose equivalent; $\mathrm{BLS}=$ Below land surface. 


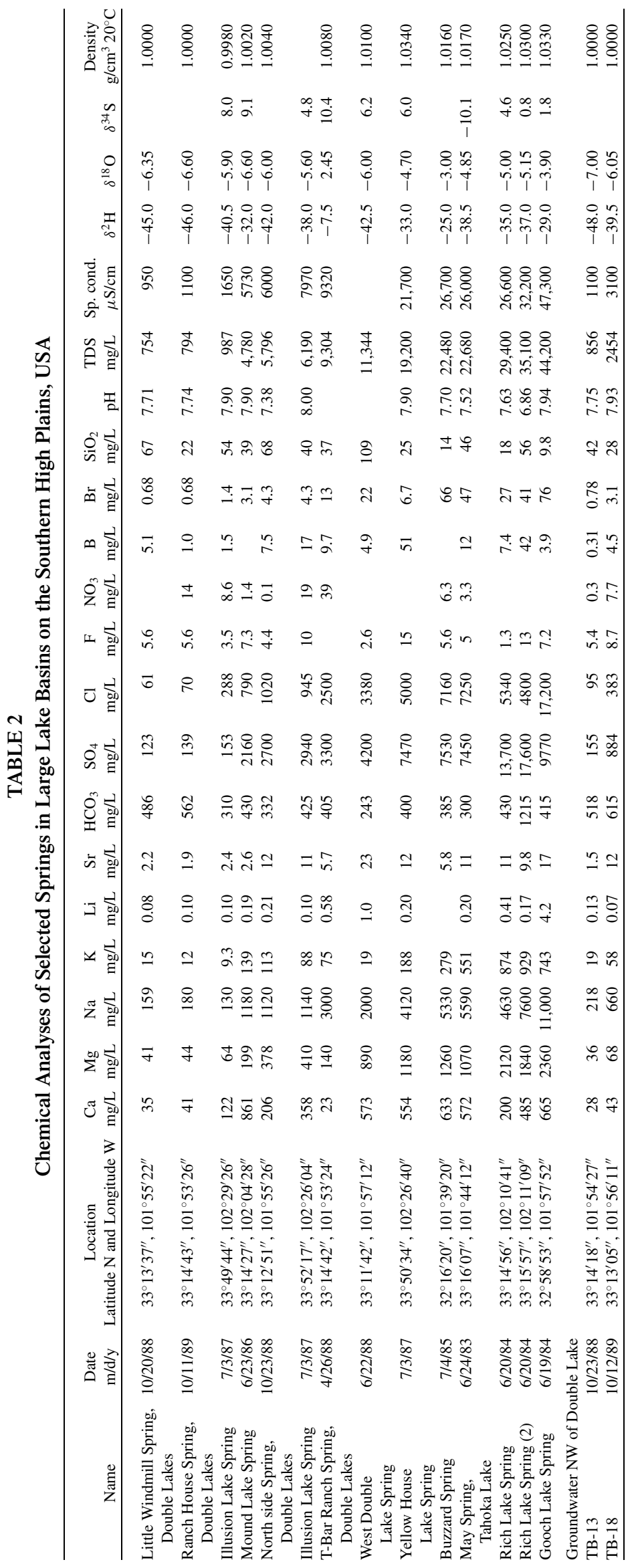


and the short sampling interval required to determine the rate of accretion, we have dated the sediments using single aliquot regenerative optical dating method applied to sand-sized quartz grains from within the lunettes (Rich et al., 1999). A continuous, vertical, $17.7-\mathrm{m}$ core was collected near the highest elevation of the innermost lunette adjacent to Double Lakes $\left(33^{\circ} 13^{\prime} 15^{\prime \prime} \mathrm{N}\right.$, $101^{\circ} 54^{\prime} 08^{\prime \prime} \mathrm{W}$, elevation $963 \mathrm{~m}$ ) (Table 1). A 5-cm-diameter, 1.5-m-long, longitudinally split core barrel raised and lowered by wire line inside a hollow-stem auger was used to collect the core. Core recovery was greater than $95 \%$. The core barrel was split longitudinally in a light-free environment beneath a large, black plastic tarpaulin adjacent to the drilling rig. Core ends were discarded, and the core was subsampled at approximately $0.5-\mathrm{m}$ intervals using empty, black plastic, $35-\mathrm{mm}$ film containers that were pushed into the side of the core and then capped. The tarp was removed, and the remaining core was examined for color and textural changes. No clear indication of paleosols was observed in the upper $14.6 \mathrm{~m}$; however, there was a distinct color change to darker red and greater compaction/cementation below this depth. The details of this and other lunettes on the SHP will be provided in a companion paper (Rich, personal communication).

\section{DISCUSSION}

Late Pleistocene and Holocene sediment deposition in the lunette nearest the lake floor falls into three relevant age assemblages of approximately $11,500 \pm 1100,6500 \pm 700$, and $4900 \pm 500$ yr B.P. (Table 1). These ages compare favorably to previously identified arid periods and are consistent with the model of dynamic equilibrium between the decline in elevation of the water table and eolian exhumation of the lake floors. An older period of aridity at approximately $109,000 \pm 11,000 \mathrm{yr}$ B.P. is also recorded in this lunette (Table 1) but is not relevant to our discussion.

It appears that immediately prior to $11,500 \pm 1100 \mathrm{yr}$ B.P., the water table declined, allowing sediment to accrete on the lunette. With one sample of less than a meter thickness, however, it is difficult to be definitive. After that episode, the groundwater table either recovered to its previous level or remained constant until $6500 \pm 700 \mathrm{yr}$ B.P. At that time, the water table must have declined significantly and rapidly, drying the lacustrine sediments and thus allowing rapid accumulation of at least $10.6 \mathrm{~m}$ of sediment within a few hundred years. The water table either recovered or remained constant until $4900 \pm 500 \mathrm{yr}$ B.P., when it again dropped, permitting accumulation of approximately $3.5 \mathrm{~m}$ of sediment on the crest of the lunette. The accumulated sediment at each of these intervals is a minimum as erosion may have removed material from the lunette.

With the lunette data alone, it is impossible to determine how long aridity remained, because once the elevation of the floor attained new equilibrium with the new water level, little additional sediment would have been transported to the lunettes. It is assumed that the water level recovered after each of these arid events rather than continue to drop throughout the Holocene be- cause semiarid climates usually are punctuated by periods of intense aridity rather than increasing aridity over time.

Evaporation of groundwater from the large lake basins would reduce the discharge of spring flow at the escarpment downgradient from the lakes. For example, it was shown above that the annual discharge of a 1-km-wide strip at the eastern escarpment would be approximately $2.2 \times 10^{9} \mathrm{~L}$. A lake with a floor surface area of $5 \mathrm{~km}^{2}$ evaporates approximately one fourth of the potential evaporation $(2 \mathrm{~m})$, or approximately $500 \mathrm{~L} / \mathrm{m}^{2} / \mathrm{yr}$ (Wood and Sanford, 1995b), and the total annual evaporation from the lake floor would be $2.5 \times 10^{9} \mathrm{~L}$. This large water loss from the flow path intersecting the lake clearly reduces the discharge flux along this flow path at the eastern escarpment. This evaporation effect, however, would not affect discharge from parallel flow lines a few kilometers on either side of the large lake basin.

Because of the large storage capacity of the High Plains aquifer system and thus, the long residence time of the water, it can be concluded that water quantity and quality in the High Plains aquifer during the Holocene was not appreciably different from that at present. It is known, however, that water quality is locally controlled by eolian activity that mobilizes efflorescent salts from the floors of the lake basins (Wood and Sanford, 1995b) and that significant differences in solute chemistry occurs among springs in these lakes (Table 2; Brune, 1981). Although some analyses indicate water quality suitable for drinking, for example, Little Windmill (Double Lakes) and Ranch House (Double Lakes), and those given in Brune (1981), other analyses indicate water quality suitable only for medicinal purposes. Consumption of water from springs with high concentrations of magnesium sulfate-Epsom salts-[Rich Lake Spring (2), West Double Lakes Spring, and Gooch Lake Spring, Table 2] could have provided a laxative effect. Thus, springs in these lakes may have served multiple purposes throughout the Holocene.

\section{SUMMARY AND CONCLUSIONS}

Eolian processes, with repeated filling and exhumation, formed the large basins. The erosion depth of the lake floors by eolian processes is controlled by the elevation of the water table; thus, the elevation of the basin floor would have fluctuated over time, depending on the elevation of the water table. Although the mouths of the springs would have declined in elevation with a declining water table, little technology by indigenous Americans would have been required (pushing away the soft sediment) to keep pace with the change in elevation. The springs will migrate up and down the side of the basin but continue to discharge to the basin relatively independent of the changes in climate.

From a hydrologic perspective, the relation among eolian process, elevation of the groundwater table, and spring discharge at the large lake basins suggests that springs in the sides of these basins may have provided continuous water during periods of aridity. Because the basins were widely distributed in the southwestern half of the SHP, they had the potential to support a 
significant number of individuals over a large geographic area. We believe that this concept is applicable not only to the SHP, but also to other arid and semiarid geographic areas with winderodible material, and over different geologic time frames. The significance of these lake sites to the understanding of human habitation patterns during periods of drought, however, awaits additional archaeological research and testing.

\section{ACKNOWLEDGMENTS}

We thank Mr. Cass Edwards, Owner, and Frank McLelland, Foreman, of the T-Bar Ranch at Double Lakes for access. Support from the University of Oxford Graduate Studies Committee, Pembroke College, Oxford, the Dudley Stamp Memorial Fund, School of Geography, Oxford, and St. John's College, Oxford University, is gratefully acknowledged. We wish to thank Edward Landa and Dennis Woodward of the USGS and Professors Vance Holliday, University of Wisconsin, and David Meltzer, Southern Methodist University, for their thoughtful, insightful reviews. Publication is approved by the Director of the U. S. Geological Survey.

\section{REFERENCES}

Bowler, J. M. (1983). Lunettes as indices of hydrologic change: A review of Australian evidence. Proceedings of the Royal Society of Victoria 3, 147168.

Brand, J. P. (1953). "Cretaceous of Llano Estacado of Texas: Report of Investigation No. 20." Texas Bureau of Economic Geology, Austin, TX.

Brune, G. (1981). "Springs of Texas" (vol. 1). Branch-Smith, Fort Worth, TX. Cember, H. (1969). "Introduction to Health Physics." Pergamon, New York.

Cronin, J. G. (1964). "A Summary of the Occurrence and Development of Ground Water in the Southern High Plains of Texas: Water Supply Paper 1693." U.S. Geol. Survey, Reston, VA.

Curtis, D. A., and Beierman, H. (1980). "Playa Lakes Characterization Study." U.S. Department of Interior, Fish and Wildlife Service, Division of Ecological Services, Ft. Worth, TX.

Forman, S. L., Oglesby, R., and Webb, R. S. (2001). Temporal and spatial patterns of Holocene dune activity on the Great Plains of North America: Megadroughts and climate links. Global and Planetary Change 29, 1-29.

Frye, J. C., and Leonard, A. B. (1957). "Studies of Cenozoic Geology along the Eastern Margin of Texas High Plains, Armstrong to Howard County: Texas Bureau of Economic Geology Report 32." University of Texas, Austin, TX.

Gustavson, T. C., and Winkler, D. A. (1988). Depositional facies of the MiocenePliocene Ogallala formation, northwest Texas and eastern New Mexico. Geology 16, 203-206.

Gustavson, T. C., Baumgardner, R. W., Caran, S. C., Holliday, V. T., Mehnert, H. H., O'Neill, J. M., and Reeves, C. C., Jr. (1991). Quaternary geology of the Southern Great Plains and adjacent segment of the Rolling Plains. In "The Geology of North America Quaternary Nonglacial Geology-Conterminous U.S." (vol. K-2), pp. 477-501. Geol. Soc. Am., Boulder, CO.

Gustavson, T. C., Holliday, V. T., and Hovorka, S. D. (1995). "Origin and Development of Playa Basins, Source of Recharge to the Ogallala Aquifer, Southern High Plains, Texas and New Mexico: Report of Investigation 229." Univ. of Texas at Austin, Bureau of Economic Geology.

Gutentag, E. D., Heimes, F. J., Krothe, N. C., Lucky, R. R., and Weeks, J. B. (1984). "Geohydrology of the High Plains Aquifer in Parts of Colorado, Kansas, Nebraska, New Mexico, Oklahoma, South Dakota, Texas, and Wyoming: Professional Paper 1500-B.” U.S. Geol. Survey, Reston, VA.

Hawley, J. W., Bachman, G. O., and Manley, K. (1976). Quaternary stratigraphy in the Basin and Range and Great Basin Provinces, New Mexico and western Texas. In "Quaternary Stratigraphy of North America" (W. C. Mahaney, Ed.), pp. 235-274. Dowden, Hutchinson and Ross Inc., Stroudsburg, PA.
Hofman, J. L. (1989). "Prehistory culture history-hunters and gatherers in the Southern Great Plains. In "From Clovis to Comanchero: Archeological Overview of the Southern Great Plains" (J. L. Hofman et al., Eds.), pp. 25-60. Archeological Survey Research Series 35, Fayetteville, AR.

Holliday, V. T. (1995). "Stratigraphy and Paleoenvironments of Late Quaternary Valley Fills on the Southern High Plains: Memoir 186." Geol. Soc. Am., Boulder, CO.

Holliday, V. T. (2000). Folsom drought and episodic drying on the Southern High Plains from 10,900 to $10,200{ }^{14} \mathrm{C}$ yr B.P. Quaternary Research 53, 1-13.

Holliday, V. T. (2001). Stratigraphy and geochronology of upper Quaternary eolian sand on the Southern High Plains of Texas and New Mexico, United States. Bulletin of the Geological Society of America 113, 88-108.

Johnson, E., and Holliday, V. T. (1986). The archaic record at Lubbock Lake. In "Current Trends in Southern Plains Archaeology: Plains Anthropologist Memoir 21” (T. G. Baugh, Ed.), pp. 7-54. Plains Anthropological Society, Lincoln, NE.

Johnson, E., and Holliday, V. T. (1995). Archaeology and late Quaternary environments of the southern high plains. Bulletin of the Texas Archeology Society 66, 519-540.

Kelly, R. L. (1995). "The Foraging Spectrum: Diversity in Hunter-Gather Lifeways." Smithsonian Institution Press, Washington, DC.

Knowles, T., Nordstrom, P., and Klemt, W. B. (1984). "Evaluating the Groundwater Resources of the High Plains of Texas: Report 288" (vol. 1). Texas Department of Water Resources, Austin, TX.

Larkin, T. J., and Bomar, W. W. (1983). “Climate Atlas of Texas: LP-192.” Texas Department of Water Resources, Austin, TX.

Meltzer, D. J. (1995). Modeling the prehistoric response to Altithermal climates on the Southern High Plains. In "Ancient Peoples and Landscapes" (E. Johnson, Ed.), pp. 349-368. Museum of Texas Tech Univ., Lubbock, TX.

Meltzer, D. J. (1999). Human responses to Middle Holocene (Altithermal) climates on the North American Great Plains. Quaternary Research 52, 404416.

National Oceanic and Atmospheric Administration. (2002). 〈http://www.srh. noaa.gov/lub/climate/records1.html .

Osterkamp, W. R., and Wood, W. W. (1984). Development and escarpment retreat of the Southern High Plains. In "Proceeding of the Ogallala Aquifer Symposium II: Lubbock, Texas" (G. A. Whetstone, Ed.), pp. 177-193. Water Resources Center, Texas Tech Univ., Lubbock, TX.

Osterkamp, W. R., and Wood, W. W. (1987). Playa-lake basins on the Southern High Plains of Texas and New Mexico: Part I-Hydrologic, geomorphic, and geologic evidence for their development. Geological Society of America Bulletin 99, 215-223.

Osterkamp, W. R., Fenton, M. M., Gustavson, T. C., Hadley, R. F., Holliday, V. T., Morrison, R. B., and Toy, T. J. (1987). "Great Plains, Centennial Special Volume 2." Geol. Soc. Am., Boulder, CO

Reeves, C. C., Jr. (1966). Pluvial lake basins of West Texas. Journal of Geology 74, 269-291.

Reeves, C. C., Jr., and Reeves, J. A. (1996). "The Ogallala Aquifer" (vol. 1). Estacado Books, Lubbock, TX.

Rich, J., Stokes, S., and Wood, W. W. (1999). Holocene chronology for lunette dune deposition on the Southern High Plains, USA. Zeitschrift für Geomorphologie, Supplmentband 116, 165-180.

Sheehan, M. (1994). Cultural response to the Altithermal: The role of aquiferrelated water resources. Geoarchaeology 9, 113-137.

Sanford, W. E., and Wood, W. W. (1995). A paleohydrologic record from lake brine on the Southern High Plains. Geology 23, 229-232.

Stokes, S. (1994). "Optical Dating of Selected Aeolian Sediments from the Southwestern United States." Ph.D. dissertation, Univ. of Oxford, Oxford, United Kingdom.

Theis, C. V. (1937). Amount of ground-water recharge in the Southern High Plains. Transactions of the American Geophysical Union 18, 564-568. 
White, W. N., Broadhurst, W. L., and Lang, J. W. (1946). "Ground Water in the High Plains of Texas: Water Supply Paper 889-F." U.S. Geol. Survey, Reston, VA.

Wirojanagud, P., Kreitler, C. K., and Smith, D. A. (1986). "Numerical Modeling of Regional Ground-Water Flow in the Deep-Basin Brine Aquifer of the Palo Duro Basin, Texas Panhandle: Report of Investigation No. 159.” Texas Bureau of Economic Geology, Austin, TX.

Wood, W. W., and Osterkamp, W. R. (1987). Playa-lake basins on the Southern High Plains of Texas and New Mexico: Part II-a hydrologic model and mass-balance arguments for their development. Geological Society of America Bulletin 99, 224-230.
Wood, W. W., and Sanford, W. E. (1995a). Chemical and isotopic methods for quantifying ground-water recharge in a regional, semi-arid environment. Ground Water 33, 458-468.

Wood, W. W., and Sanford, W. E. (1995b). Eolian transport, saline lake basins, and ground-water solutes. Water Resources Research 31, 3121-3129.

Wood, W. W., Sanford, W. E., and Reeves, C. C., Jr. (1992). Large lake basins of the Southern High Plains: Ground-water control of their origin? Geology 20, 535-538.

Wood, W. W., Rainwater, K. A., and Thompson, D. B. (1997). Quantifying macropore recharge: Examples from a semi-arid area. Ground Water 35, $1097-1106$ 